\title{
Prediction of methane emission from sheep based on data measured in vivo from open-circuit respiratory studies
}

\author{
Tao Ma', Kaidong Deng ${ }^{2}$, and Qiyu Diao ${ }^{1, *}$
}

* Corresponding Author: Qiyu Diao Tel: +86-10-8210-6055, Fax: +86-10-6216-9105,

E-mail: diaoqiyu@caas.cn

${ }^{1}$ Feed Research Institute, Chinese Academy of Agricultural Sciences, Key Laboratory of Feed Biotechnology of the Ministry of Agriculture, Beijing 100081, China

${ }^{2}$ College of Animal Science, Jinling Institute of

Technology, Nanjing, Jiangsu 210038, China

ORCID

Tao Ma

https://orcid.org/0000-0003-4821-836X

Kaidong Deng

https://orcid.org/0000-0002-5037-1892

Qiyu Diao

https://orcid.org/0000-0002-8037-1471

Submitted Nov 6, 2018; Revised Dec 31, 2018; Accepted Jan 14, 2019
Objective: The current study analysed the relationships between methane $\left(\mathrm{CH}_{4}\right)$ output from animal and dietary factors.

Methods: The dataset was obtained from 159 Dorperxthin-tailed Han lambs from our seven studies, and $\mathrm{CH}_{4}$ production and energy metabolism data were measured in vivo by an opencircuit respiratory method. All lambs were confined indoors and fed pelleted diet during the whole experimental period in all studies. Data from two-thirds of lambs were used to develop linear and multiple regressions to describe the relationship between $\mathrm{CH}_{4}$ emission and dietary variables, and data from the remaining one third of lambs were used to validate the established models.

Results: $\mathrm{CH}_{4}$ emission (g/d) was positively related to dry matter intake (DMI) and gross energy intake (GEI) $(\mathrm{p}<0.001) . \mathrm{CH}_{4}$ energy/GEI was negatively related to metabolizable energy/gross energy and metabolizable energy/digestible energy $(\mathrm{p}<0.001)$. Using DMI to predict $\mathrm{CH}_{4}$ emission $(\mathrm{g} / \mathrm{d})$ resulted in a coefficient of determination $\left(\mathrm{R}^{2}\right)$ of 0.80 . Using GEI, digestible energy intake, and metabolizable energy intake predict $\mathrm{CH}_{4}$ energy/GEI resulted in a $\mathrm{R}^{2}$ of 0.92 .

Conclusion: the prediction equations established in the current study are useful to develop appropriate feeding and management strategies to mitigate $\mathrm{CH}_{4}$ emissions from sheep.

Keywords: Methane; Sheep; Prediction Equation; Digestible Energy; Metabolisable Energy

\section{INTRODUCTION}

There are increasing concerns about the impact of livestock production on the environment. Methane $\left(\mathrm{CH}_{4}\right)$, a greenhouse gas that remains in the atmosphere for approximately 9 to 15 years, is over 25 times more effective in trapping heat in the atmosphere than carbon dioxide $\left(\mathrm{CO}_{2}\right)$ [1]. Livestock farming is a major contributor to atmospheric $\mathrm{CH}_{4}$ accumulation. In ruminants, approximately $95.5 \%$ of $\mathrm{CH}_{4}$ generation is produced by fermentation of feed in the rumen [2], which causes a loss of $2.3 \%$ to $10.8 \%$ of feed energy depending on the diet and animal [3]. Therefore, national inventories of greenhouse gas emissions are essential for the quantification of these emissions from individual countries and the elaboration of country level mitigation strategies [4]. However, due to the complexity in determining $\mathrm{CH}_{4}$ production in vivo, prediction equations are essential to accurately estimate $\mathrm{CH}_{4}$ emission from ruminants, which is necessary to provide useful strategies for the feeding and management of animals. Although the prediction equation of $\mathrm{CH}_{4}$ emission has been established for sheep by different researchers [5-8], it should be noted diet, animal breed, and management system could all contribute to errors when developing national $\mathrm{CH}_{4}$ emission inventories [9].

The sheep production in China differs from that in Australia and in Europe, which are 
almost exclusively dependent upon pasture [10,11]. China is featured by vast population and scarce land per capita, as well as limited forests and pastureland [12]. Since the beginning of the 21st century, the Chinese Government has further implemented polices including "Control grazing for grassland recovery" to conserve grasslands, mitigate degradation, and promote economic development in pastoral regions [13]. On the other hand, China has long history of sheep domestication and currently there are 162.06 million sheep in China, accounting for about $14 \%$ of total sheep population in the whole world. Consequently, modern sheep production system in China features limited or even no grazing and the sheep are mainly fed on crop residues. Therefore, it is uncertain if those prediction model based on $\mathrm{CH}_{4}$ production from grazing sheep can also accurately predict $\mathrm{CH}_{4}$ production from sheep under current feeding conditions in China, which contribute substantially to the world greenhouse emissions due to the large sheep population.

The indigenous breeds such as $\mathrm{Hu}[14]$ and thin-tailed Han (small tail Han) [15] sheep are famous for high prolificacy and non-seasonal ovulatory activity. With the introduction of Dorper sheep from Australia in 2001 [16], Dorper sheepxthintailed Han crossbred sheep has become a predominant breed for meat-producing in China. In recent years, the nutrient requirements of Dorper $\times$ thin-tailed Han crossbred sheep in terms of energy [17-20], protein [21-23], and minerals [24] have been extensively studied and reported. Based on those conditions, dataset used in the current study to provide basic $\mathrm{CH}_{4}$ emission parameters were obtained from the same breed
(Dorper $\times$ thin-tailed Han), feeding conditions (confined indoors), and feeding regime (pelleted diet), which largely mirrors the current characteristics of sheep production system in China. Therefore, in current study, practical equations were established using dataset from our seven previous studies to predict $\mathrm{CH}_{4}$ production from Dorper $\times$ thin-tailed Han crossbred lambs. Our objective was to provide basic information for the establishment of robust national $\mathrm{CH}_{4}$ inventories and practical mitigation strategies to reduce the environmental impact of sheep production systems.

\section{MATERIALS AND METHODS}

\section{Animals and diets}

The dataset used in the present study was obtained from 159 lambs in seven energy metabolism studies undertaken as part of the National Technology Program for the Meat Sheep Industry of China from 2010 to 2015 [17-20,25-27]. The animals were offered pelleted diet in all studies with concentrate:forage ratio ranging from 12:88 to 92:8. The concentrate included corn, soybean, barley, oat, wheat, sorghum, soybean meal, rapeseed meal, cottonseed meal, peanut meal, and dry distillers grains with solubles, and the roughage included Chinese wild rye hay (Leymus chinensis) and corn stalk. The data, composed of means, standard deviations and ranges for animal and dietary variables, are presented in Table 1 . In each experiment the animals were offered the experimental diets for 4 weeks in group-housed pens before conducting the digestion and respirometry trial to measure energy metabolism.

Table 1. Animal and dietary data $(n=159)$

\begin{tabular}{|c|c|c|c|c|}
\hline Items & Mean & SD & Minimum & Maximum \\
\hline \multicolumn{5}{|c|}{ Body weight, feed intake and methane data } \\
\hline BW (kg) & 35.4 & 5.31 & 23.5 & 48.9 \\
\hline $\operatorname{NDFl}(\mathrm{kg} / \mathrm{d})$ & 0.46 & 0.16 & 0.13 & 0.81 \\
\hline GEI (MJ/d) & 18.6 & 5.04 & 8.05 & 36.6 \\
\hline $\operatorname{DMD}(\%)$ & 61.6 & 7.25 & 48.2 & 78.4 \\
\hline Methane emission (L/kg DMI) & 37.6 & 6.6 & 18.8 & 54.1 \\
\hline Methane energy output (MJ/d) & 1.55 & 0.55 & 0.56 & 3.52 \\
\hline Methane energy output/GEI (\%) & 8.37 & 1.77 & 3.79 & 12.0 \\
\hline \multicolumn{5}{|c|}{ Dietary nutrient (kg/kg DM) and energy (MJ/kg DM) concentration } \\
\hline DM & 911.4 & 18.6 & 890.0 & 960.0 \\
\hline $\mathrm{DE}$ & 11.2 & 1.5 & 4.6 & 15.6 \\
\hline ME & 8.9 & 1.5 & 2.2 & 13.2 \\
\hline
\end{tabular}

SD, standard deviation; BW, bodyweight; DMI, dry matter intake; NDFI, neutral detergent fibre intake; GEl, gross energy intake; DMD, dry matter digestibility; OMD, organic matter digestibility; DM, dry matter; CP, crude protein; NDF, neutral detergent fibre; GE, gross energy; DE, digestible energy; ME, metabolisable energy. 
The digestion and respirometry trial comprised a 10- $\mathrm{d}$ collection period after a 10-d adaptation period. During the 10-d collection period, feed offered, orts, and faeces were weighed and sampled ( $10 \%$ of total weight) daily. Urine was acidified with $100 \mathrm{~mL}$ of $1.8 \mathrm{M} \mathrm{H}_{2} \mathrm{SO}_{4}$ daily and measured for volume, and $1 \%$ was sampled daily. As outlined in Deng et al [17], methane production was measured using an open-circuit respirometry system (Sable Systems International, Las Vegas, NV, USA) integrated with 3 metabolism cages each equipped with a polycarbonate head box. On d 0, 2, 4, 6, and 8 of the 10 -d collection period, each group of lambs was moved into the metabolism cages for methane assessment. After a $24-\mathrm{h}$ adaptation period, individual methane production was measured over a 24 -h period. Methane concentration as well as temperature, humidity, dew point and air flow rate were recorded and processed using the Sable Systems software to calculate individual sheep methane production.

\section{Statistical analysis}

Prediction equations for methane emission were developed using dry matter intake (DMI), neutral detergent fibre intake (NDFI), gross energy intake (GEI), digestible energy intake (DEI), metabolizable energy intake (MEI), dietary metabolisable energy/digestible energy (ME/DE), $\mathrm{DE} /$ gross energy (GE) or ME/GE as predictors in multiple regressions. A stepwise multiple regression technique was used to develop multiple prediction equations, and the technique automatically selects the best and significant predictors to fit the prediction equations. Experimental effects on these relationships were removed by the following model:

$$
y=a_{i}+b_{1} x_{1}+b_{2} x_{2}+\ldots+b_{n} x_{n}
$$

where, $a_{i}$ represents the effect of experiment $i$ for $i=1$ to 5 , $x_{1}, x_{2}, \ldots x_{n}$ are the $\mathrm{x}$-variables and $b_{1}, b_{2}, \ldots b_{n}$ are their regression coefficients. The statistical program used in the present study was Genstat (Version 18.1; VSN International Ltd, Hemel Hempstead, England, 2015).

\section{RESULTS}

Correlation between methane emission and feed intake as well as energy digestibility and metabolisability The relationships between $\mathrm{CH}_{4}$ and feed intake as well as energy digestibility and metabolisability are shown in Table 2 . Total $\mathrm{CH}_{4}$ output (L/d) was linearly correlated with feed intake (DMI and NDFI) and energy intake (GEI, DEI, and MEI) ( $\mathrm{p}<0.001) . \mathrm{CH}_{4}$ emission expressed as $\mathrm{L} / \mathrm{kg} \mathrm{DMI}$ was linearly correlated with DMI, GEI, DEI ( $\mathrm{p}<0.05)$, and NDFI $(\mathrm{p}<0.01)$. A similar relationship was also observed between $\mathrm{CH}_{4}$ energy/ GEI and DMI, NDFI, GEI, and DEI. $\mathrm{CH}_{4}$ emission expressed as $\mathrm{L} / \mathrm{kg}$ NDFI was linearly correlated with DEI $(\mathrm{p}<0.01)$ and MEI ( $\mathrm{p}<0.05)$. Total $\mathrm{CH}_{4}$ output (L/d), $\mathrm{CH}_{4}(\mathrm{~L} / \mathrm{kg} \mathrm{DMI})$, and $\mathrm{CH}_{4}$ energy/GEI negatively correlated with $\mathrm{ME} / \mathrm{GE}(\mathrm{p}<0.01)$, while $\mathrm{CH}_{4}$ (L/kg NDFI) positively correlated with DE/GE $(p<0.01)$ and $\mathrm{ME} / \mathrm{GE}(\mathrm{p}<0.05)$, and negatively correlated with $\mathrm{ME} / \mathrm{DE}(\mathrm{p}<0.05)$.

\section{Prediction equations for methane emission and validation of the equations}

Using two-thirds of the data, linear regression was established between total $\mathrm{CH}_{4}$ emission (L/d) and DMI $(\mathrm{g} / \mathrm{d})\left(\mathrm{R}^{2}=0.80\right)$ and NDFI $(\mathrm{g} / \mathrm{d})\left(\mathrm{R}^{2}=0.76\right)$, respectively (Table 3$)$. As the variation in $\mathrm{CH}_{4}$ production was best predicted by these two parameters, multiple linear prediction equations were developed using DMI and NDFI $\left(\mathrm{R}^{2}=0.85\right)$. Linear regression was established between total $\mathrm{CH}_{4}$ energy (MJ/d) and GEI (MJ/d) $\left(R^{2}=0.80\right)$. Multiple regression was established between total $\mathrm{CH}_{4}$ energy (MJ/d) and combination of GEI, DEI, and MEI $(\mathrm{MJ} / \mathrm{d})$ and the $\mathrm{R}^{2}$ of the regression was 0.92 . Further validation of those regression models was conducted using the remaining one third of the data (Table 3). The results showed

Table 2. Significant levels for the linear relationships between methane output from animal and dietary factors

\begin{tabular}{|c|c|c|c|c|}
\hline Items & $\mathrm{CH}_{4}(\mathrm{~L} / \mathrm{d})$ & $\mathrm{CH}_{4}(\mathrm{~L} / \mathrm{kg}$ DMI) & $\mathrm{CH}_{4}(\mathrm{~L} / \mathrm{kg} \mathrm{NDFI})$ & $\mathrm{CH}_{4}$ energy/GEI \\
\hline \multicolumn{5}{|l|}{ Feed intake } \\
\hline DMI (kg/d) & $+{ }^{* *}$ & $+{ }^{*}$ & & $+^{*}$ \\
\hline $\operatorname{NDFI}(\mathrm{kg} / \mathrm{d})$ & $+{ }^{* *}$ & $+{ }^{* *}$ & - & $+{ }^{* *}$ \\
\hline GEI (MJ/d) & $+* *$ & $+{ }^{*}$ & & $+{ }^{*}$ \\
\hline DEI (MJ/d) & $+* *$ & $+^{*}$ & $+* *$ & + \\
\hline MEI (MJ/d) & $+{ }^{* *}$ & & $+^{*}$ & \\
\hline \multicolumn{5}{|c|}{ Energy digestibility and metabolisability } \\
\hline $\mathrm{DE} / \mathrm{GE}$ & - & - & $+* *$ & - \\
\hline $\mathrm{ME} / \mathrm{GE}$ & $-{ }^{* *}$ & $--^{* *}$ & $+^{*}$ & $--^{* *}$ \\
\hline $\mathrm{ME} / \mathrm{DE}$ & $-{ }^{* *}$ & $-* *$ & $-{ }^{*}$ & $-* *$ \\
\hline
\end{tabular}

DMI, dry matter intake; NDFI, neutral detergent fibre intake; GEI, gross energy intake; DEl, digestible energy intake; MEl, metabolisable energy intake; DE, digestible energy; $\mathrm{GE}$, gross energy; $\mathrm{ME}$, metabolisable energy.

'+/-' represents $0.1<p<0.05 ;{ }^{*}+{ }^{*}{ }^{* \prime}$ represents $0.05<p<0.01 ;{ }^{\prime}+{ }^{* *} /{ }^{* * \prime}$ represents $p<0.01$. 
Table 3. Linear and multiple regression for $\mathrm{CH} 4$ output using feed intake and energy digestibility and metabolisability

\begin{tabular}{|c|c|c|c|c|c|}
\hline Items & Equation & $\mathrm{R}^{2}$ & SE & Predicted & Actual \\
\hline $\mathrm{CH}_{4}(\mathrm{~L} / \mathrm{d})$ & $=-5.45( \pm 2.98)+0.043( \pm 0.003) \times \mathrm{DMl}(\mathrm{g} / \mathrm{d})$ & 0.80 & 9.30 & 38.7 & 39.9 \\
\hline $\mathrm{CH}_{4}(\mathrm{~L} / \mathrm{d})$ & $=2.23( \pm 2.76)+0.08( \pm 0.006) \times \mathrm{NDFl}(\mathrm{g} / \mathrm{d})$ & 0.76 & 9.93 & 41.0 & \\
\hline $\mathrm{CH}_{4}(\mathrm{~L} / \mathrm{d})$ & $=-6.20( \pm 2.74)+0.027( \pm 0.004) \times \mathrm{DMI}(\mathrm{g} / \mathrm{d})+0.039( \pm 0.009) \times \mathrm{NDFI}(\mathrm{g} / \mathrm{d})$ & 0.85 & 8.54 & 40.4 & \\
\hline $\mathrm{CH}_{4}$ energy $(\mathrm{MJ} / \mathrm{d})$ & $=-0.19( \pm 0.11)+0.093( \pm 0.006) \times \mathrm{GEI}(\mathrm{MJ} / \mathrm{d})$ & 0.80 & 0.36 & 1.50 & 1.57 \\
\hline $\mathrm{CH}_{4}$ energy $(\mathrm{MJ} / \mathrm{d})$ & $=-0.34( \pm 0.06)+0.043( \pm 0.008) \times \mathrm{GEI}(\mathrm{MJ} / \mathrm{d})+0.65( \pm 0.04) \times \mathrm{DEI}(\mathrm{MJ} / \mathrm{d})-0.70( \pm 0.04) \times \mathrm{MEI}(\mathrm{MJ} / \mathrm{d})$ & 0.92 & 0.19 & 1.60 & \\
\hline
\end{tabular}

SE, standard error; DMI, dry matter intake; NDFI, neutral detergent fibre intake; GEl, gross energy intake; DEl, digestible energy intake; MEl, metabolisable energy intake.

that the average of predicted $\mathrm{CH}_{4}(\mathrm{~L} / \mathrm{d})$ using equations with DMI (38.7), NDFI (41.0), or both DMI and NDFI (40.4) as predicting factors was very close to the actual average of $\mathrm{CH}_{4}$ output (30.0). Similarly, the average of predicted $\mathrm{CH}_{4}$ energy $(\mathrm{MJ} / \mathrm{d})$ using equations with GEI (1.50), and a combination of GEI, DEI, and MEI (1.60) as predicting factors was also close to the actual average of $\mathrm{CH}_{4}$ energy (1.57).

Validation of previously published prediction equations for sheep emissions

The present study used datasets from seven studies $(\mathrm{n}=159)$ to validate previously published prediction equations for $\mathrm{CH}_{4}$ emission from sheep (Table 4). The $\mathrm{CH}_{4}$ emission (g/d) was under-predicted by Zhao et al [8] but over-predicted by Bell et al [7]. The $\mathrm{R}^{2}$ for the relationship between predicted and actual $\mathrm{CH}_{4}$ emission (g/d) was close to 0.70 . The $\mathrm{CH}_{4}$-E was over-predicted using either DMI and GEI by Patra et al [6], or GEI, DEI, or MEI by Zhao et al [8]. The $\mathrm{R}^{2}$ for the relationship between predicted and actual $\mathrm{CH}_{4}-\mathrm{E}$ was greatest in Patra et al [6] using DMI $\left(\mathrm{R}^{2}=0.70\right)$ or GEI $\left(\mathrm{R}^{2}=0.71\right)$ and in Zhao et al [8] using GEI $\left(R^{2}=0.71\right)$, while the lowest $R^{2}$ was observed using MEI as the prediction factor $\left(\mathrm{R}^{2}=0.44\right)$. A lower $\mathrm{CH}_{4} / \mathrm{DMI}$ was obtained from the predicted value of $\mathrm{Zhao} \mathrm{et}$ al [8] and our results (20.8 vs $27.2 \mathrm{~g} / \mathrm{kg}$ ). However, the $\mathrm{CH}_{4}$ energy/GEI predicted by Zhao et al [8] was only $71 \%(5.95 /$ $8.37 \times 100)$ of that measured in the current study. The $\mathrm{R}^{2}$ in the relationship between predicted and actual $\mathrm{CH}_{4} / \mathrm{DMI}$ and $\mathrm{CH}_{4}$-E/GEI was the 0.62 and 0.59 , respectively.

\section{DISCUSSION}

In the current study, average $\mathrm{CH}_{4}$ emission was $39.9 \mathrm{~L} / \mathrm{d}$ or $28.9 \mathrm{~g} / \mathrm{d}$, which was comparable to that of Dorper crossbred sheep measured using chambers reported by Nie et al [28] (39.7 L/d) and Zhao et al [8] (37.2 L/d). Furthermore, our result was within the range (12.2 to $37.3 \mathrm{~g} / \mathrm{d})$ in studies of grazing sheep summarized by Savian et al [29]. The average $\mathrm{CH}_{4}$ scaled to DMI was $37.6 \mathrm{~L} / \mathrm{kg}$ or $27.2 \mathrm{~g} / \mathrm{kg}$ in the current study, which was considerably greater than that (16.5 to 21.1 $\mathrm{g} / \mathrm{kg}$ ) reported for sheep fed perennial ryegrass $[8,30]$. Furthermore, the lower limit of $\mathrm{CH}_{4}$ emission scaled to DMI (18.8 $\mathrm{L} / \mathrm{kg}$ or $13.6 \mathrm{~g} / \mathrm{kg}$ ) in the current study was close to that of Welsh Mountain sheep fed on permanent pasture $(14.4 \mathrm{~g} / \mathrm{kg})$ or Molinia sheep $(14.1 \mathrm{~g} / \mathrm{kg})$ [31]. In the current study, pelleted diets were used in all experiments, which theoretically can be more rapidly digested and thus promoting feed intake [32]. A study suggested that pelleting could increase DMI by $45 \%$ in sheep, especially for young animals [33], compared with grass. Similarly, we also observed higher DMI $(1.04 \mathrm{~kg} / \mathrm{d})$ compared with others $[8,30,31]$, which could be attributed to the pelleted diet used in our series of studies. Although it was reported that increasing feed intake can reduce $\mathrm{CH}_{4}$ production per unit of feed intake [8], the substantial higher $\mathrm{CH}_{4}$ emission $(28.9 \mathrm{~g} / \mathrm{d})$ compared with others $[8,30,31]$ could be responsible for the higher $\mathrm{CH}_{4}$ emission scaled to DMI in the current study. Pinares-Patiño et al [34] reported a lower $\mathrm{CH}_{4}$ emission (22.0 g/kg DMI) from ewes also fed pelleted diet

Table 4. Published equations used for validation of present results

\begin{tabular}{|c|c|c|c|c|c|}
\hline References & & Equations & Predicted & Actual & $\mathbf{R}^{2}$ \\
\hline Bell et al [7] & $\mathrm{CH}_{4}(\mathrm{~g} / \mathrm{d})$ & $=18+22.5 \times \mathrm{DMI}(\mathrm{kg} / \mathrm{d})$ & 41.5 & 28.2 & 0.70 \\
\hline Zhao et al [8] & & $=3.1+16.7 \times \mathrm{DMI}(\mathrm{kg} / \mathrm{d})$ & 20.6 & & 0.70 \\
\hline \multirow[t]{2}{*}{ Patra et al [6] } & $\mathrm{CH}_{4}$ energy $(\mathrm{MJ} / \mathrm{d})$ & $=0.223+0.876 \times \mathrm{DMI}(\mathrm{kg} / \mathrm{d})$ & 1.14 & 1.56 & 0.70 \\
\hline & & $=0.208+0.049 \times \mathrm{GEI}(\mathrm{MJ} / \mathrm{d})$ & 1.13 & & 0.71 \\
\hline \multirow[t]{3}{*}{ Zhao et al [8] } & & $=0.17+0.050 \times \mathrm{GEI}(\mathrm{MJ} / \mathrm{d})$ & 1.11 & & 0.71 \\
\hline & & $=0.21+0.060 \times \mathrm{DEI}(\mathrm{MJ} / \mathrm{d})$ & 0.91 & & 0.58 \\
\hline & & $=0.26+0.064 \times \mathrm{MEI}(\mathrm{MJ} / \mathrm{d})$ & 0.86 & & 0.44 \\
\hline Zhao et al [8] & $\mathrm{CH}_{4}(\mathrm{~g} / \mathrm{kg} \mathrm{DMI})$ & $=-2.7+7.9 \times \mathrm{DE}(\mathrm{MJ} / \mathrm{kg})-7.3 \times \mathrm{ME}(\mathrm{MJ} / \mathrm{kg})$ & 20.8 & 27.2 & 0.62 \\
\hline Zhao et al [8] & $\mathrm{CH}_{4}$ (energy/GEI) & $=(0.022 \times \mathrm{DE}[\mathrm{MJ} / \mathrm{kg}]-0.021 \times \mathrm{ME}[\mathrm{MJ} / \mathrm{kg}]) \times 100$ & 5.95 & 8.37 & 0.59 \\
\hline
\end{tabular}

DMI, dry matter intake; GEl, gross energy intake; DEl, digestible energy intake; MEl, metabolisable energy intake; $\mathrm{DE}$, digestible energy; $\mathrm{ME}$, metabolisable energy. 
measured using chambers. However, it should be noted that the pelleted diet used in their study contained less neutral detergent fibre (NDF, $269 \mathrm{~kg} / \mathrm{kg}$ DM vs $429 \mathrm{~kg} / \mathrm{kg} \mathrm{DM}$ ). Dietary NDF concentration has been proved to be positively correlated with $\mathrm{CH}_{4}$ production for ruminants [35]. It was unexpected that $\mathrm{CH}_{4}$ emission measured using $\mathrm{SF}_{6}$ ranged from 26.7 to $27.9 \mathrm{~g} / \mathrm{kg}$ DMI for grazing sheep reported by Savian et al [29], which was almost identical to our result. This might be due to the high NDF content in Italian ryegrass (from 586 to $606 \mathrm{~kg} / \mathrm{kg} \mathrm{DM}$ ) used in their study. Despite of the dietary factors mentioned above, animal factors (breed, sex, and growth stage) as well as measurement technique can also have influence on $\mathrm{CH}_{4}$ emission and therefore should be taken into consideration in the development of mitigation strategies.

$\mathrm{CH}_{4}$ emission as a proportion of energy losses accounts for $3.79 \%$ to $12.0 \%$ of GEI in the current study, which was comparable to the range reported in cattle (2\% to $15 \%)$ [36]. The average ratio of $\mathrm{CH}_{4}$ to total GEI in this study (8.4\%) was higher than the average value reported for grazing sheep $(6.2 \%)[8,29,30]$. The lower energy utilization efficiency could be again explained by the high passage rate and low nutrient digestibility of sheep fed pelleted diet in the current study. For example, dry matter digestibility (DMD, 61.6\%) and organic matter digestibility (OMD, 61.8\%) observed in the current study were significantly lower compared with DMD reported by Moorby et al [31] (72.2\%) and Zhao et al [8] (73\%), and OMD reported by Fraser et al [30] (66.2\%). Intergovernmental Panel on Climate Change Tier 2 methodology [37] currently uses GEI along with a standard $\mathrm{CH} 4$ conversion factor $\left(\mathrm{CH}_{4}\right.$ energy/GE $\left.=6.5 \%\right)$ to calculate $\mathrm{CH}_{4}$ emissions, thus, probably underestimating $\mathrm{CH}_{4}$ emission from sheep under the experimental conditions in the current study.

In the current study body weight (BW) was not significantly correlated with $\mathrm{CH}_{4}$ emission from sheep. Similarly, it is reported that $\mathrm{BW}$ alone is a poor variable for predicting $\mathrm{CH}_{4}$ emission in grazing beef cattle $\left(\mathrm{R}^{2}=0.27\right)$ [9] and sheep $\left(\mathrm{R}^{2}=0.25\right)[6]$, and it was found that metabolic BW was marginally correlated with $\mathrm{CH}_{4}$ energy $\left(\mathrm{R}^{2}=0.49\right)$ in goats [38], indicating that the accuracy of using BW to predict $\mathrm{CH}_{4}$ emission might be affected by feeding conditions.

Feed intake is often used to predict $\mathrm{CH}_{4}$ production in inventory models. In the present study, DMI is the main determinant of total $\mathrm{CH}_{4}$ emission $\left(\mathrm{R}^{2}=0.80\right)$, a result similar to that obtained by Patra et al [6] in sheep $\left(\mathrm{R}^{2}=0.83\right)$. It is well documented that $\mathrm{CH}_{4}$ emission (L/d) from enteric fermentation in sheep is closely related to total feed intake $[8,39]$. A strong relationship between DMI and $\mathrm{CH}_{4}$ emission was also reported in beef and dairy cattle $\left(\mathrm{R}^{2}=0.68\right)$ [40]. A quadratic relationship between $\mathrm{CH}_{4}$ energy and DMI in dairy cows was also observed [41]. However, a study suggested that the prediction equations based on DMI as primary pre- dictors of $\mathrm{CH}_{4}$ output resulted in a relatively weak $\mathrm{R}^{2}(0.44)$ in beef cattle [40]. This might suggest that the inclusion of other variables, such as BW and dietary nutrient concentrations, may be important to improve the predictive accuracy of regression models. Nevertheless, Ellis et al [40] reported that NDFI $(\mathrm{kg} / \mathrm{d})$ was the best predictor of $\mathrm{CH}_{4}$ production $\left(\mathrm{R}^{2}=0.66\right)$ in beef cattle, and further combination of DMI and NDFI could also robustly predict $\mathrm{CH}_{4}$ emission from cattle $\left(R^{2}=0.67\right)$, which was in accordance with the regression models established in our study. The NDF fraction contains cell-wall fractions such as cellulose, hemicellulose, and lig$\operatorname{nin}$ [42]. The positive relationship between NDFI $(\mathrm{kg} / \mathrm{d})$ and $\mathrm{CH}_{4}$ production in the current study along with the study by Ellis et al [40] might be explained by the dietary NDF concentration, which could improve ruminal fermentation and lead to preferable high acetate:propionate ratio that facilitates $\mathrm{CH}_{4}$ production [43], making it an easily measured predictor of $\mathrm{CH}_{4}$ production within a regression model.

Energy intake (GEI alone or GEI, DEI and MEI) is also effective prediction factors of $\mathrm{CH}_{4}$ emission in the current study, which are in accordance with those observed in cattle $[9,40,44]$. In agreement with Molano and Clark [45], the quantity of $\mathrm{CH}_{4}$ emission, per unit of DMI or GE losses as $\mathrm{CH}_{4}$ was not affected by the level of DMI. In the current study, there was a negative relationship between $\mathrm{CH}_{4} / \mathrm{GEI}$ and dietary $\mathrm{ME}$ concentrations or $\mathrm{ME} / \mathrm{DE}$, which is similar to that reported in beef [9] and dairy cattle [46], indicating that an improved feed utilisation efficiency could reduce $\mathrm{CH}_{4}$ emissions. On the other hand, we observed a positive correlation between DMI and $\mathrm{CH}_{4} / \mathrm{GEI}$, which is inconsistent with previous result in dairy cow [46] and sheep [8]. Indeed, an increase in feeding level (DMI) increases the outflow rate of digesta and thus reduces ruminal nutrient digestion, leading to decrease in $\mathrm{CH}_{4}$ [46]. However, in the current study, sheep with higher DMI also consumed relatively more concentrate than those with lower DMI. Previous study suggested that ruminal nutrient digestion increased with increasing concentrate intake [47], which in turn result in the increase in $\mathrm{CH}_{4}$ output. Therefore, the positive correlation DMI and $\mathrm{CH}_{4} /$ GEI observed in the current study can be expected.

Due to the scarcity of relevant studies for sheep, predicted $\mathrm{CH}_{4}$ emission parameters using equations from 3 published papers were compared with the actual $\mathrm{CH}_{4}$ production in the current study. Both Bell et al [7] and Zhao et al [8] developed prediction models for enteric $\mathrm{CH}_{4}$ emissions using sheep in $\mathrm{UK}$, where the sheep production is featured by long grazing seasons [48]. Therefore, the use of those equations in confined-feeding animals must be with caution. Patra et al [6] established prediction model for $\mathrm{CH}_{4}$ emission based on the results of more than 1,500 sheep. Although the equations in their study might be more inclusive, it should be noted that the predicting equations established in the current study were 
more specific in the method (respiratory chamber) used and feeding conditions (confined and fed pelleted diet), which could be more accurate to calculate the $\mathrm{CH}_{4}$ inventory under similar conditions.

\section{CONCLUSION}

In the present study, a range of prediction equations for methane production from sheep was based on in vivo data from open-circuit respiratory studies. Strong relationships were found between methane production and animal or dietary factors including DMI, NDFI, and GEI. These equations are useful to develop appropriate feeding and management strategies for mitigating methane emission from sheep under current feeding system in China.

\section{CONFLICT OF INTEREST}

We certify that there is no conflict of interest with any financial organization regarding the material discussed in the manuscript.

\section{ACKNOWLEDGMENTS}

This research was supported by the National Natural Science Foundation of China (Grant No: 41705129 and 41475126) and by the earmarked fund for the China Agriculture Research System (CARS-38).

\section{REFERENCES}

1. Knox SH, Sturtevant C, Matthes JH, Koteen L, Verfaillie J, Baldocchi D. Agricultural peatland restoration: effects of landuse change on greenhouse gas $\left(\mathrm{CO}_{2}\right.$ and $\left.\mathrm{CH}_{4}\right)$ fluxes in the Sacramento-San Joaquin Delta. Global Change Biol 2015;21: 750-65. https://doi.org/10.1111/gcb.12745

2. AGO. National greenhouse gas inventory 2001 with methodology supplements. Canberra, Australia; 2003.

3. Guyader J, Eugène M, Noziere P, Morgavi DP, Doreau M, Martin C. Influence of rumen protozoa on methane emission in ruminants: a meta-analysis approach. Animal 2014;8:181625. https://doi.org/10.1017/S1751731114001852

4. Moraes LE, Strathe AB, Fadel JG, Casper DP, Kebreab E. Prediction of enteric methane emissions from cattle. Global Change Biol 2014;20:2140-8. https://doi.org/10.1111/gcb.12471

5. Pelchen A, Peters KJ. Methane emissions from sheep. Small Rumin Res 1998;27:137-50. https://doi.org/10.1016/S09214488(97)00031-X

6. Patra AK, Lalhriatpuii M, Debnath BC. Predicting enteric methane emission in sheep using linear and non-linear statistical models from dietary variables. Anim Prod Sci 2016;56: 574-84. https://doi.org/10.1071/AN15505
7. Bell M, Eckard R, Moate PJ, Yan T. Modelling the effect of diet composition on enteric methane emissions across sheep, beef cattle and dairy cows. Animal 2016;6:54. https://doi. org/10.3390/ani6090054

8. Zhao YG, O'Connell NE, Yan T. Prediction of enteric methane emissions from sheep offered fresh perennial ryegrass (Lolium perenne) using data measured in indirect open-circuit respiration chambers. J Anim Sci 2016;94:2425-35. https://doi. org/10.2527/jas.2016-0334

9. Yan T, Porter MG, Mayne CS. Prediction of methane emission from beef cattle using data measured in indirect open-circuit respiration calorimeters. Animal 2009;3:1455-62. https:// doi.org/10.1017/S175173110900473X

10. Wright ADG, Williams AJ, Winder B, Christophersen CT, Rodgers SL, Smith KD. Molecular diversity of rumen methanogens from sheep in Western Australia. Appl Environ Microbiol 2004;70:1263-70. https://doi.org/10.1128/AEM.70.3.12631270.2004

11. De Rancourt M, Fois N, Lavín MP, Tchakérian E, Vallerand F. Mediterranean sheep and goats production: An uncertain future. Small Rumin Res 2006;62:167-79. https://doi.org/ 10.1016/j.smallrumres.2005.08.012

12. Yang H, Li X. Cultivated land and food supply in China. Land Use Policy 2000;17:73-88. https://doi.org/10.1016/S02648377(00)00008-9

13. Zhang Y, Huang D, Badgery WB, et al. Reduced grazing pressure delivers production and environmental benefits for the typical steppe of north China. Sci Rep 2015;5:Article number: 16434. https://doi.org/10.1038/srep16434

14. Feng W, Ma Y, Zhang Z, Zhou D. Prolific breeds of China. In: Fahmy MH, editor. Prolific sheep. Wallingford, UK: CAB International Press; 1996. p. 146-51.

15. Chu MX, Ji CL, Chen GH. Association between PCR-RFLP of melatonin receptor la gene and high prolificacy in Small Tail Han sheep. Asian-Australas J Anim Sci 2003;16:1701-4. https://doi.org/10.5713/ajas.2003.1701

16. Zhao F, Wang G, Zeng T, et al. Estimations of genomic linkage disequilibrium and effective population sizes in three sheep populations. Livest Sci 2014;170:22-9. https://doi.org/10.1016/ j.livsci.2014.10.015

17. Deng KD, Diao QY, Jiang CG, et al. Energy requirements for maintenance and growth of Dorper crossbred ram lambs. Livest Sci 2012;150:102-10. https://doi.org/10.1016/j.livsci. 2012.08.006

18. Deng KD, Jiang CG, Tu Y, et al. Energy requirements of Dorper crossbred ewe lambs. J Anim Sci 2014;92:2161-9. https:// doi.org/10.2527/jas.2013-7314

19. Xu GS, Ma T, Ji SK, et al. Energy requirements for maintenance and growth of early-weaned Dorper crossbred male lambs. Livest Sci 2015;177:71-8. https://doi.org/10.1016/j.livsci.2015. 04.006

20. Ma T, Xu GS, Deng KD, et al. Energy requirements of early- 
weaned Dorper cross-bred female lambs. J Anim Physiol Anim Nutr 2016;100:1081-9. https://doi.org/10.1111/jpn.12481

21. Deng KD, Ma T, Jiang CG, et al. Metabolizable protein requirements of Dorper crossbred ram lambs. Anim Feed Sci Technol 2017;223:149-55. https://doi.org/10.1016/j.anifeedsci.2016. 11.009

22. Ma T, Deng K, Tu Y, et al. Protein requirements of earlyweaned Dorper crossbred female lambs. J Integr Agric 2017; 16:1138-44. https://doi.org/10.1016/S2095-3119(16)61455-7

23. Ma T, Deng K, Tu Y, et al. Net protein and metabolizable protein requirements for maintenance and growth of earlyweaned Dorper crossbred male lambs. J Anim Sci Biotechnol 2017;8:40. https://doi.org/10.1186/s40104-017-0172-6

24. Ji S, Xu G, Diao Q, et al. Macromineral requirements of Dorper $\times$ Thin-tailed Han Crossbred female lambs. J Integr Agric 2015;14:1617-26. https://doi.org/10.1016/S2095-3119(14) 60901-1

25. Zhao YG, Diao QY, Liu J, Jiang CG, Deng KD, Tu Y. Estimation and regression models of methane emissions from sheep. Sci Agric Sin 2012;45:2718-27.

26. Zhao J, Wei S, Ma T, et al. Establishment of prediction model of metabolizable energy of concentrate for mutton sheep by substitution method. Chinese J Anim Nutr 2016;28:121744 (in Chinese).

27. Ding J, Cheng S, Deng K, Zhang M, Diao Q, Tu Y. Effects of different neutral detergent fiber/nonfiberous carbohydrate diets on methane emission of meat sheep. Chinese J Anim Nutr 2017;29:806-13 (in Chinese).

28. Nie HT, Wan YJ, You JH, et al. Effect of age on energy requirement for maintenance and growth of Dorper and Hu crossbred F1 ewes weighing 20 to $50 \mathrm{~kg}$. Asian-Australas J Anim Sci 2015;28:1140-9. https://doi.org/10.5713/ajas.14.0403

29. Savian JV, Neto AB, de David DB, et al. Grazing intensity and stocking methods on animal production and methane emission by grazing sheep: implications for integrated crop-livestock system. Agric Ecosyst Environ 2014;190:112-9. https://doi. org/10.1016/j.agee.2014.02.008

30. Fraser MD, Fleming HR, Theobald VJ, Moorby JM. Effect of breed and pasture type on methane emissions from weaned lambs offered fresh forage. J Agric Sci 2015;153:1128-34. https:// doi.org/10.1017/S0021859615000544

31. Moorby JM, Fleming HR, Theobald VJ, Fraser MD. Can live weight be used as a proxy for enteric methane emissions from pasture-fed sheep? Sci Rep 2015;5: Article number:17915. https://doi.org/10.1038/srep17915

32. Hammond KJ, Pacheco D, Burke JL, Koolaard JP, Muetzel S, Waghorn GC. The effects of fresh forages and feed intake level on digesta kinetics and enteric methane emissions from sheep. Anim Feed Sci Technol 2014;193:32-43. https://doi.org/10. 1016/j.anifeedsci.2014.04.005

33. Greenhalgh JFD, Reid GW. The effects of pelleting various diets on intake and digestibility in sheep and cattle. Anim Sci
1973;16:223-33. https://doi.org/10.1017/S0003356100030075

34. Pinares-Patiño CS, McEwan JC, Dodds KG, et al. Repeatability of methane emissions from sheep. Anim Feed Sci Technol 2011;166-167:210-8. https://doi.org/10.1016/j.anifeedsci. 2011.04.068

35. Ellis JL, Kebreab E, Odongo NE, McBride BW, Okine EK, France J. Prediction of methane production from dairy and beef cattle. J Dairy Sci 2007;90:3456-66. https://doi.org/10.3168/ jds.2006-675

36. Johnson KA, Johnson DE. Methane emissions from cattle. J Anim Sci 1992;73:2483-92. https://doi.org/10.2527/1995. $7382483 \mathrm{x}$

37. IPCC (Intergovernmental Panel on Climate Change). Emissions from livestock and manure management. In: Guidelines for national greenhouse inventories. Vol. 4. Agriculture, forestry and other land use; Geneva, Switzerland: IPCC; 2006.

38. Patra AK, Lalhriatpuii M. Development of statistical models for prediction of enteric methane emission from goats using nutrient composition and intake variables. Agric Ecosyst Environ 2016;215:89-99. https://doi.org/10.1016/j.agee. 2015.09.018

39. Blümmel M, Givens DI, Moss AR. Comparison of methane produced by straw fed sheep in open-circuit respiration with methane predicted by fermentation characteristics measured by an in vitro gas procedure. Anim Feed Sci Technol 2005;123124:379-90. https://doi.org/10.1016/j.anifeedsci.2005.06.001

40. Ellis JL, Kebreab E, Odongo NE, et al. Modeling methane production from beef cattle using linear and nonlinear approaches. J Anim Sci 2009;87:1334-45. https://doi.org/10.2527/ jas.2007-0725

41. Yan T, Mayne CS. Mitigation strategies to reduce methane emission from dairy cows. In Proceedings of the BGS/BES/ BSAS Conference: High Value Grassland: Providing Biodiversity, a Clean Environment and Premium Products; 2007; Apr 17-9; Staffordshire, UK. University of Keele; 2007. p. 345-8.

42. Van Soest PJ, Robertson JB, Lewis BA. Methods for dietary fiber, neutral detergent fiber, and nonstarch polysaccharides in relation to animal nutrition. J Dairy Sci 1991;74:3583-97.

43. Benchaar C, Pomar C, Chiquette J. Evaluation of dietary strategies to reduce methane production in ruminants: A modelling approach. Can J Anim Sci 2001;81:563-74. https://doi.org/10. 4141/A00-119

44. Mills JAN, Kebreab E, Yates CM, et al. Alternative approaches to predicting methane emissions from dairy cows. J Anim Sci 2003;81:3143-50. https://doi.org/10.2527/2003.81123141x

45. Molano G, Clark H. The effect of level of intake and forage quality on methane production by sheep. Aust J Exp Agric 2008;48:219-22. https://doi.org/10.1071/EA07253

46. Yan T, Mayne CS, Gordon FG, et al. Mitigation of enteric methane emissions through improving efficiency of energy utilization and productivity in lactating dairy cows. J Dairy Sci 2010;93:2630-8. https://doi.org/10.3168/jds.2009-2929 
47. Archimède H, Sauvant D, Schmidely P. Quantitative review of ruminal and total tract digestion of mixed diet organic matter and carbohydrates. Reprod Nutr Dev 1997;37;173-89.

48. Pacheco D, Waghorn G, Janssen H. Decreasing methane emissions from ruminants grazing forages: a fit with productive and financial realities? Anim Prod Sci 2014;54:1141-54. https://doi.org/10.1071/AN14437 